is no direct evidence in the new material that Oppenheimer had indeed been a Communist.

Deborah Shapley

Soviet radio-catastrophe

Another theory

Washington

What did happen in the southern Ural mountains in 1957-58? Did buried radioactive waste explode? Or was the landscape blighted and thousands of people hurt by a strange weather pattern that rained fallout from Soviet atomic bomb tests in the north?

The disaster has been a mystery since it surfaced in the West in a Copenhagen newspaper report in 1958 that implied that a Soviet weapons test had gone awry, and speculation grew into controversy in 1976 when Zhores Medvedev, a prominent Soviet dissident scientist living in London, alleged there had been a catastrophic, volcano-like explosion from buried nuclear wastes in a secret area near the city of Kyshtym.

Now a new theory has been advanced by the Los Alamos Scientific Laboratory, that links the disaster, among other things, with acid rain. The public summary of a classified report concludes that there was no single catastrophic explosion of buried wastes, and certainly not an explosion involving nuclear criticality. Instead, widespread damage to the land and population was caused by "a series of relatively minor incidents ... . severely compounded by a history of sloppy practices" at a plutonium production plant.

The new report confirms the allegations of Medvedev and Soviet scientist Lev Tumerman, who drove through the region in 1960, in their horrid accounts of burned people and devastated land. It recounts that there were "death squads" of radioactively contaminated prisoners assigned to work in the area, essentially until they dropped dead.

The site of the alleged disaster was a plutonium production plant built for the Soviet weapons programme east of the city of Kyshtym on the site of a munitions plant that operated under the Tsars. The plutonium plant was apparently built in the late 1940s, after the Smyth and Groves reports had been published explaining how the United States had built its atomic weapons during the war. The report indicates that the Soviet Kyshtym plant was modelled on the US plutonium plant at Hanford, Washington, and that, the Soviet Union had detailed information about Hanford practices and procedures. The evidence for this, however, is not given.

So, the report says, a city was built having "thousands" of workmen and engineers. A graphite-moderated, uranium-fuelled reactor was built, called "Unit O". Cooling water from Unit O was pumped into a large artificial lake dug on the grounds. Later, the cooling water from

\section{Rorvik disowned}

New York

Dr Derek Bromhall, formerly of the University of Oxford, has won his suit against journalist David Rorvik and the publisher Lippincott and Company. On the third day of the trial this month (see Nature 1 April, p.383) and before a single scientist had taken the witness stand, the defendants settled out of court. The settlement is important not only because it amounts to a public disavowal by the publishers of Rorvik's book, published in 1978 under the title In His Image: the Cloning of a Human, but also because it is a precedent for other complaints of the unauthorized use of scientific data in popular works.

In an apology to Dr Bromhall which accompanied the settlement (said to amount to some hundreds of thousands of dollars) Martin H. Lippincott, Chief Executive Officer of the publishers, conceded that "this company now believe the story to be untrue" and acknowledged that "Dr Bromhall did not consent to the inclusion of his name or his research techniques in the book and also that Dr Bromhall never engaged in, or attempted to engage, or advocated the cloning of a human being. We regret any embarrassment, humiliation, or other injury to him that the reference to Dr Bromhall in the book might have caused".

Lippincott and Company had promoted the book, about an unnamed American millionaire financing the birth of his clone, as non-fiction.

Judge John Fullam of the United States District Court, who had been hearing Dr Bromhall's suit last year, called the book "a fraud and a hoax"' Apparently Lippincott began withholding royalty cheques from $\mathrm{Mr}$ Rorvik as soon as the initial suit began.

As Dr Bromhall is no longer an academic scientist, the direct damage to him from the book where his cloning techniques were quoted would have been difficult to prove, according to observers. Only the threat of punitive damages forced the hasty end to the trial. Michael Stein

at least two reactors built there was also pumped into the lake. Fuel-rod cladding failures were probably frequent, the report says, so the rods leaked material. By 1953 , the lake had become dangerously radioactive.

The lake fed into the Techa River, a slow-moving stream along which lived a primitive Bashkir people. Soon, the Techa, too, became "a chronic, waterborne source of radioactive contamination" long before any of the dates of alleged disasters. To separate plutonium from the irradiated fuel elements would have needed nitric acid. The off-gas belched yellow smoke out from a high smokestack, 24 hours a day for years on end. Because of the high humidity of the region, the Los Alamos theory goes, the nitrogen oxides in the gas'would have produced acid rain and acid-laden snow which could have caused the "dead" landscape seen by Tumerman.

The Soviet Union was in such a hurry to get as much bomb-grade material as possible that the irradiated fuel elements were not allowed to cool, so the gases from the plant would have included radioactive iodine as well. The authors of the report say that the impact of the consequent acid rain would have been appalling. A third source of contamination was the burial of radioactive wastes from the late 1940 s and the $1950 \mathrm{~s}$. The wastes were not put in steel tanks as at Hanford but radioactive liquid waste̊ was simply dumped into a dry lakebed 5 or 6 kilometres south-east of the plutonium complex.

People in the Techa River region began having radiation sickness, crops were killed by acid rain and the stackgases. So, the report says, the authorities must have evacuated the Bashkirs and burned their homes. This would account for the burned buildings, and for the disappearance of local villages - signs Medvedev interpreted as indications of a nuclear disaster.

The Los Alamos report, like others, confirms that the landscape of the region was changed mightily in the late 1950 s. The report includes "before" and "after" maps showing that new lakes were created, drainage canals dug to circumvent other lakes, and so on. All this, it seems, was necessary to stem the contamination of the Techa.

If there were explosions, the report concludes, they would have been chemical, not nuclear. Likely causes cited include ammonium nitrate and hexone, a flammable solvent often used in waste separation.

The report is the latest in a chain of Western "explanations" for the disaster. Curiously, one of the report's two authors, Danny Stillman a Los Alamos staff member, was a co-author of an earlier Los Alamos report attributing the disaster to fallout from "dirty" atomic weapons tests to the north at Novaya Zemlya, and a meteorological fluke that dumped the fallout southwards. Stratton was not available to discuss why the theory has changed: nor was the other author, Diane M. Soran. However, Harold Agnew, a former Los Alamos director who is president of General Atomic Corporation, and who coauthored the Novaya Zemblya theory, says the new theory is an improvement.

The proponents of the buried nuclear waste explosion theory are not convinced. Medvedev says that the report is simply wrong. The people who lived in the area were not simple Bashkir tribesmen as claimed in the report - the Bashkir Republic is somewhere else: the villages that disappeared after the disaster all have Russian names, and therefore had Russian inhabitants.

Moreover, Medvedev says his notion all 